\title{
Novels and Short Stories from Macau: Two Different Perspectives
}

\author{
JOSÉ I. SUÁREZ \\ University of Northern Colorado
}

\begin{abstract}
Critical studies about the Macanese and their literature in the former Portuguese colony of Macau have been scant. Novelists like Austin Coates (City of Broken Promises, 1967) from Great Britain and Henrique de Senna Fernandes (A trança feiticeira, 1993) from Macau, as well as short story writers Deolinda da Conceição (Macau) and Maria Ondina Braga (Portugal), depict life in colonial Macau. While the plots of these works display similarities, Coates's and Braga's perspectives are filtered through the lenses of European colonialism and Fernandes and da Conceição work through the legacy of coloniality.
\end{abstract}

Keywords: Miscegenation, colonialism, coloniality, fetish, subaltern

Except for a few scholarly articles and a monograph, critical studies on the Macanese (i.e., inhabitants of Portuguese ancestry or Catholic Chinese and their descendants) and their literature in the former Portuguese colony of Macau have been scant. The individual perspectives of novelists like Austin Coates (City of Broken Promises, 1967) from Great Britain and Henrique de Senna Fernandes (A trança feiticeira, 1993) from Macau, as well as the short story writers Deolinda da Conceição (Macau) and Maria Ondina Braga (Portugal), depict life in colonial Macau. The plots of these works display similarities; however, Coates and Braga's perspectives are filtered through the lenses of European colonialism, while Fernandes and da Conceição work through the attitudinal legacy of 
coloniality-i.e., racist modes of interaction generated in colonized societies by the rise of capitalism during modernity (Mignolo).

An in-depth examination of British and Iberian colonial practices is beyond the scope of this article; however, it must be observed that "miscegenation" has long been a feature of Iberian imperialism, and attention to this phenomenon further differentiates Macanese and Portuguese fiction on Macau from Coates's work. Coates was admittedly a Lusophile who passed away in Sintra, Portugal; nevertheless, his novel reflects a deeply British colonial mindset.

Before moving to an analysis of prose fiction from Macau, it is worth making three historical points. Macau was the first European colony established in Asia (1554) and it was also the last one, ceded in 1999 to China. Throughout the latter half of the nineteenth century, the Portuguese specialized in the trafficking of manual labor and opium distribution. Beyond this, they also sold Chinese females of all ages as sex slaves, thereby inflicting a humiliating "colonial wound” on the region. Like Hong Kong, Macau also never gained territorial independence, and its situation thus falls squarely within the scope of postcolonial studies. ${ }^{1}$

\section{Novels}

Women subalterns are protagonists in both novels. City of Broken Promises fictionalizes the life of Martha M(i)erop, an eighteenth-century Chinese orphan "comfort girl” turned businesswoman, whose rags-to-riches tale would have been impossible if not for her amorous relationship with Thomas Kuyck van Mierop, a functionary of the British East Indian Company (which imposed the sale and consumption of opium on the Chinese). The title of the novel is derived from the common practice of the British, in Macau as well as in Hong Kong, of promising marriage to their Asian mistresses, only to forsake them and their illegitimate offspring upon leaving the colonies.

In A trança feiticeira, A-Leng, a Chinese water carrier, is seduced by a Macanese, Adozinho, who ends up falling in love with her. Most of the novel narrates the tribulations endured by the couple after being ostracized by their respective groups. A-Leng's braid, a fetish of Adozinho's sexual desire and a

\footnotetext{
${ }^{1}$ Macau's status as a special administrative region of China was determined with Portugal years before the publication of A trança feiticeira.
} 
symbol of her exoticism and "Otherness," gives the work its title. This object obsession is typical in colonial discourse, where "the recognition of sexual difference [...] is disavowed by the fixation on an object that masks that difference. [...] The functional link between the fixation of the fetish and the stereotype (or the stereotype as fetish) is even more relevant” (Bhabha 74). The braid enables Adozinho to fixate on a symbol rather than on the person, and the result is that he can more easily ignore those differences that will lead to a transgression, one that will put him at odds with those around him. The braid is likewise a metonymy for conquest and sexual possession.

Fetishism is also part of Coates's novel, but falls more within the realm of miscegenation. Martha is described by the narrator as having "up-tilted and almond-shape" eyes, pale smooth skin, fine black hair, a small child-like round face and dimples (21-22). Christina Miu Bing Cheng insightfully points out that "these racial stereotypes perhaps render the image of an 'outlandish doll' and constitute a kind of epidermal fetishism that fosters Mierop's fascination with miscegenation. Martha is also [...] reified as an object of sexual desire. Exoticization and eroticization of a Chinese girl appear to be the chief motifs in this colonialist novel” (“Colonial Stereotyping” 137). An attempt to lessen her "Otherness" and to place her within a European context is realized through the following observations: "her black dress [...] was more European than Chinese;" "she was a good deal more mature than most European girls of such an age;" "joining her hands [...], she subdues her enthusiasm [...] a gesture that made her seem suddenly very European” (21-23).

The British Empire imposed a rigidly stratified form of colonial governance and exploitation in their African and Asian territories. With the exception perhaps of India, British colonies were comprised of a dominant group (i.e., the British themselves), the East Indian buffer group brought in to serve as "the canary in the coal mine," and the subalterns, made up of natives and/or imported laborers. Jamaica provides an excellent example. There one finds, in addition to the dominant and buffer groups, enslaved Africans and their descendants serving as subaltern subjects once the original inhabitants, the Arawaks, had been exterminated. In Macau, however, Coates finds himself writing a novel that adds another layer of complexity to the structure. There are subalterns and the dominant British, but there is also a subdominant group, namely the Portuguese. In City of Broken Promises, Anglo characters, including the narrator, manifest 
their prejudices toward Catholic Portuguese (Coates makes no distinction between Peninsular Portuguese and mestizo Macanese) and the "inscrutable" Chinese. For example, the narrator observes that "all that concerns the Portuguese is old and decrepit” (7) after having described the city as an infested extension of Europe, "subdued by Roman Catholic superstitions" (6). He also describes Macau as "priest-ridden [with] so many churches for such a small population” (8). Thomas himself, supposedly more open-minded, avers his strong dislike of the Portuguese in a diary entry: "I detest all that part of Macao which is Portuguese” (158). It is worth noting that an integral part of British imperialism was the conversion of the colonized to Protestantism by means of Bible translations into the native language. In Macau and China, however, the British tweaked the formula by incorporating opium into the effort. Consequently, "opium and the Bible were intriguingly put side by side to the extent that it was hardly possible for the Chinese to refuse the equivalence of the Christian God to the ecstatic opium" (Macau 68).

Comments such as "fixed Asian expressions" (18) and "somber Asian eyes" (21) sprinkle the early pages of Coates's novel. The term "Macanese" appears only in reference to the local dialect spoken by the natives of the city. Martha, the subordinate orphan with no identity, believes that she can escape her "Asianness" through sheer mimicry. Such a notion, coupled with her assumption that she now has a last name, Auvrey, given to her by her adoptive French father, is put to the test when she is ejected from the Frenchman's house by his wife, Teresa da Silva, whom we assume to be Macanese, shortly after his death:

[Teresa] "You will go now with what you have on your back and nothing more."

[Martha] "I will take my rosary with me."

[Teresa] "You black-soul Chinese devil [...]; what need have you for a rosary?"

[Martha] "I am not Chi-" yet as she reached the word Chinese her voice died away. What she was trying to say was not true. She was Chinese [...], but she had been told that she was not a real Chinese, not like other Chinese who worshipped devils and would go to hell when they died. [But] it was true, then. She was 
not [...] accepted truly into the Christian family. They had all told lies to her. (64-65)

Martha, like many Macanese, believes in her superiority to the Chinese because of her conversion to Christianity.

Characterization in A trança feiticeira, although generally exempt of racist remarks, is nonetheless fashioned along colonial perspectives. Adozinho is depicted as an ethnic hybrid Macanese because of his Chinese, Portuguese, and Dutch ancestry. Fernandes explains Adozinho's European lineage, a Dutch greatgrandmother and a grandfather from northern Portugal; however, nowhere does he specify the source of the Chinese portion of his genetic makeup. Readers are only informed that Adozinho has Chinese blood when the narrator describes him physically, "Orgulhava-se [...] do seus malares de costela chinesa (Chapter 1). It could be inferred that it comes from the paternal side given that his father, Aurélio, had been a "funcionário das Alfândegas Chinesas" (Chapter 1). That he has a Portuguese name, that he is Catholic, and that the customs house where he might have worked was administered by the British in the European Settlement of Shanghai makes this inference rather farfetched (the Portuguese shut down the Taipa Chinese customs house near Macau in 1849). And, just as the British view the Portuguese as superstitious in City of Broken Promises, Adozinho and Aurélio deride as "superstições" the Chinese belief in feng shui held by the women in their household (Chapter 1).

Fernandes's reluctance, whether conscious or not, to provide the Chinese ascendency of his Creole protagonist may stem from the "coloniality of power." By downplaying the Sinic origins of Macanese like himself, Fernandes, an AsianPortuguese from Macau, tries to "lactify" them, to use Frantz Fanon's nomenclature. The Macanese were for decades the elite indigenous group, the buffer group between the dominant Portuguese and the subaltern Chinese on the island. Yet for Fernandes, as well as for Coates, the Macanese are tightly linked to the Portuguese: "The kwai-los, as all Portuguese were called [by the ethnic Chinese], regardless whether they were native sons of Macao or had come from outside, were viewed with suspicion" (16). ${ }^{2}$ It should be reemphasized that,

\footnotetext{
2 This DuBoisian double consciousness, that is, ignoring a part of one's racial makeup to acknowledge only the other, may be found in the American West, where descendants of the original Spanish settlers consider themselves "white” rather than "mestizo," as many of them actually are.
} 
whereas Fernandes's intent is to "whiten" the Macanese through their Portuguese lineage, Coates's is to dismissively lump Portuguese and Macanese together as an inferior group of "others."

George Cuming, a British character in Coates’s novel, derisively alludes to the Chinese by pointing out that the ruffled shirts worn by the British in Macau are "laundered in Calcutta" because "no Chinaman has ever known what to do with them" (33). Adozinho, on the other hand, having been publicly spurned by A-Leng, reflects on the aspect that exacerbates his humiliation, she "era uma aguadeira ou lavadeira [...] um exemplo da decantada malcriacão da gente do Cheok Chai Un” (Chapter 3). Though Cheok Chai Un is the neighborhood of the poor ethnic Chinese, Adozinho anchors his sense of superiority on socioeconomics, not on racial or ethnic factors.

In keeping with the Western Orientalist fetishization of Asian women, Martha and A-Leng are stereotypes cut from the same cloth. Each is an orphan with no legal surname (and thus no identity), and they are both illiterate, sensuous, and ostracized because of their relations with a non-Chinese man. The male protagonists, also stereotypes, are affluent, educated, and handsome Europeans (or depicted as such), who condescendingly take on Chinese women, first as lovers, then as wives. This formulaic dichotomy ensures a noble yet romantic plot: white boy meets girl of color and, through a love that develops through sexual exploitation, he delivers her from a life of penury. As Rey Chow has observed regarding David Henry Wang's anti-Orientalist play, M. Butterfly, in each novel "the superimposition of the racial and sexual elements of [the] relationship creates the space in which the story unfolds" (77). The disparity in the sexual agency provides for successful plots in both works only because of readers' Orientalist bent. Were the roles reversed-i.e., if European female protagonists had sacrificed their standing by falling in love with poor Asian men - the plots would have failed; such women would have been considered insane (Chow 79), and the plot would collapse. In addition, these works' Orientalist plot formula lends further credence to Rudyard Kipling's divisive, "Oh East is East, and West is West, and never the twain shall meet" because "the Western partner is [...] constructed as a messianic hero who rescues the Eastern

\footnotetext{
${ }^{3}$ Remnants of this homogenizing viewpoint likewise survive among Anglo-Americans, who even now tend to refer to their Latinx neighbors and family members as "Spanish."
} 
'child' from a hellish situation [thereby revealing] an unbridgeable gap between the two hemispheres through disjunctive representations" ("Colonial Stereotyping” 139).

To give answer to Gayatri Spivak’s provocative question, the two novels do allow the subaltern to speak to a certain extent, but only if we adopt a homogenized understanding of "subaltern" and a simplified definition of "to speak” (Loomba 196). Martha and A-Leng, as females of color, symbolize the most exploited of subjugated people: they belong to the lowest and most formalized class of subalterns and, as such, have no history. Both, however, ascend socially and economically through marriage, the result of having previously entered into concubinage with males of the influential class. ${ }^{4}$ Most importantly, they are fictional characters and thus part of a patriarchal construct. They speak and act as the authors (however well-meaning their intent) believe they should. Precisely because of the nonexistence of subaltern historicity, Coates, for example, feels compelled to have Martha, an alleged historical figure, provide a postmodern dialectic when she asks George Cumming, "Do I have to remind you [...] that you are no longer among the English, where your word is all important and mine means nothing?” (254). Fernandes, although he stresses that A-Leng does not forsake her Chinese roots, has her adopt the Catholic faith through baptism and church-sanctioned marriage. He thus eases matters with Adozinho's family, because Adozinho is not forced to sever ties with a religion that is his cultural tradition and that links him to the power elite. Once again, the subaltern yields to the dominant class. At the novel's end, Adozinho's father reconciles with his son by at last accepting his Chinese daughter-in-law and his grandchildren; A-Leng is also reintegrated into her own community.

\section{Short Stories}

A Portuguese journalist educated in France and the United Kingdom, Braga perceives Macanese reality often through the typically Orientalist eyes of many

\footnotetext{
${ }^{4}$ China forbade interracial marriages between Europeans and Chinese in Macau during the eighteenth century; however, such couples could wed if they chose to resettle outside the colony. Almost all Englishmen chose not to do so and abandoned their illegitimate families upon leaving the colony. Marriages between Macanese and Chinese were not forbidden, but they were uncommon generally for socioeconomic reasons.
} 
Westerners. Da Conceição, however, a native Macanese educated in the colony, depicts the sad reality encountered by Eurasian women like herself and, worse yet, that of Chinese women in a colonial setting. My aim with certain selected short stories is to contrast the topics of exoticism, miscegenation, cultural hybridity, and subaltern identity contained in the stories of da Conceição's Cheong-Sam: a cabaia and Braga's A China fica ao lado.

According to Brookshaw, whereas da Conceição and Braga display a strong thematic unity in their stories, Braga "adopts the stance of an observer from the outside” who feels obligated to enlist the assistance of a Chinese American, Mei Lai, to understand and write about Chinese culture in Macau (80). Da Conceição, on the other hand, needs no intermediary to compose a fiction based on her city and culture of origin. In this sense, while Braga's perspective, like Coates's, reflects the perspective of European colonialism, Da Conceição, like Fernandes, responds to racist colonial attitudes.

Women subalterns are protagonists in these authors' short stories. In da Conceição's "Cheong Sam,” the initial story from which the collection derives its title, A-Chung, a convicted murderer, lays out the events that led him to slay his wife, Chan Nui. Fleeing Shanghai after the Japanese occupation during the Second World War, the couple and their children endure hardship in their new home-though not mentioned, it was probably Canton, Hong Kong or Macau. Because he cannot financially provide for the family, Chan Nui, on account of her Western education, gets a job at a bar for wealthy clients. A-Chung, consumed with jealousy by his wife's interaction with powerful men, kills her with a meat cleaver. All that remains is her cheongsam, a one-piece Chinese dress that hangs behind the door.

In addition to Bradshaw's view that this is a "morality tale," it also metaphorically reveals Chinese attitudes toward Westerners. As discussed, the British, by means of two Opium Wars, imposed the sale and consumption of the drug on the Chinese. The Boxer Rebellion later manifested Chinese resentment against the West's colonial designs through its Christian missionary proxies who went to China for more than just "saving souls." Consequently, this animosity, along with Chinese hatred toward the Japanese, resulted in the 1949 Revolution that rid the country of capitalism and other Western values.

That Chan Nui had studied in the West made her suspect to most of her compatriots, including her husband. Her education, while enabling her to get a 
better-paying job, also alienated her from the culture and traditions of her forefathers. In this new position, euphemistically referred to as a "taxi girl" (though she is essentially a bar maid), she earns more than A-Chung. To him, she has menacingly become the family's main provider but, worse yet, she is challenging his masculinity by tending to powerful men, many of whom are foreigners who, to worsen matters, lavish her with expensive gifts. This situation so torments him that he ends up killing her out of feelings of jealousy and emasculation. By the end of the story, the message is clear: the West is dead and what remains is the East-the cheongsam.

This East-West dichotomy continues in other stories in da Conceição's collection. For example, in "Conflito de sentimentos," we find a Macanese mother, born and educated in the United States, who decides to follow her son to her birthplace, where he is to study. She makes up her mind to go after witnessing her husband's attempt to lure a young woman to his group of concubines. Unlike "Cheong Sam," this short story details an apparent moral victory for the West: it depicts China, and by extension the East, as a place where matrimony keeps women in a state of degrading subservience insofar as it condones concubinagea practice outlawed after the 1949 communist takeover, though compliance is still not enforced. In contrast, the United States, and by extension the West, are viewed as the paradigm for education and women's rights. Though perhaps an example of Western moral superiority, this dichotomy could be viewed as one prejudiced by a coloniality that, as previously detailed, is the legacy of a colonial mentality that was instilled and survives among the colonized.

Nowhere is the ambivalence or insecurity resulting from cultural hybridity more succinctly exemplified than in "A esmola," a short story in which an unnamed young man, the illegitimate offspring of a European father and a Chinese mother, leaves to study in the West. As he stands on the pier readying to board the ship, the author recounts the strong differences between both parents:

The father seldom spoke with her, since he understood little of her language, but he [the son] had learned to speak both languages fluently, so that he could communicate with both. He never saw them go out together, never saw them taking a stroll in each other's company, never did they exchange impressions about their life together. As far back as he could remember, he noticed that 
his father gave the orders and that his mother humbly obeyed them. At mealtime, she ate her rice with chopsticks, while he and his father used cutlery. Christmas and other holidays had no meaning at his house. When he became ill, his father took him to a European doctor; his mother, however, called for a witchdoctor. What followed was a series of arguments and misunderstandings. He was then forced to try to appease his father's anger while trying to explain to his mother why the father insisted on calling a doctor. He would listen to their bickering back and forth, feeling overwhelmed and totally exasperated. Why had he been born into this? Why? Why? (28)

What further complicates the young man's sense of identity is the unexpected conclusion of the story. He has asked his mother not to see him off at the pier, but as he starts to head for the ship, he spots a woman making her way through the crowd in his direction. He is shocked to see that his father, once aware of the woman, hurriedly leaves. As she, a working-class Chinese, draws near, the young man instinctively pulls some coins out of his vest pocket, drops them in her outstretched hands, and proceeds up the ramp. Sobbing, the woman exclaims, "he gave me alms, he gave me alms, in exchange for having given him life!" (29).

Apparently, the young man's repudiation of the mother he knows, and now of his biological mother, must stem partially from his awareness that he is an illegitimate son. Nonetheless, it also weighs on him that he was born to a coarse, ignorant, Asian woman. If she had been European, her unpolished ways might not have been a source of embarrassment, as implied by his apparent acceptance of or indifference to his white father's flaws. Consequently, his is racial selfloathing derived from what Walter Mignolo calls a byproduct of the "Western imperial humiliation [...] the traces of the colonial or the imperial wounds" (17).

Frantz Fanon had earlier set forth his socio-genetic principle that, succinctly described, is the aversion felt by Europeans and by people of color themselves toward the latter's skin color and physiognomy. Writers like da Conceição and Fernandes reflect these imperial wounds in their works, and they will continue to do so until an "epistemic revolution” takes place that enables a substantive change, one that will lead to a decolonial approach to fiction. 
As mentioned, the title of da Conceição's short-story collection is CheongSam, with its Portuguese translation, a cabaia, as its subtitle. In English, CheongSam translates to "Mandarin gown," which is a straight, close fitting silk dress with a high neck, short sleeves, and a slit skirt. Although intended to denote that the stories are by and about women, the title also serves as a symbol of the protagonists' exoticism and “Otherness.” Such allusions enable these writers to remind the reader that they are facing characters unlike themselves, characters whom they view as "others” and, at times, as inferior.

Miscegenation is part of Braga's fiction, a common topic in Portuguese colonialist discourse. In "Os Espelhos," for example, a tale about a schoolteacher who goes mad and lives in a room filled with mirrors, Braga describes her protagonist as "pequena e magra [...] mestiça de chinesa e inglês" (27). She again brings up hybridity in "feicões mistas de chinês e europeu," a phrase that she repeats in the story (103).

Like da Conceição, fetishism (here referring to an object or characteristic associated with a group) abounds in Braga's stories. She mentions the Mandarin dress throughout her collection. In addition, Chinese aristocratic women's foot binding, while expressing differences in social standing, also evinces an underlying intent to eroticize female characters. In this sense, Miu Bing Cheng insightfully points out that "these racial stereotypes perhaps render the image of an 'outlandish doll' and constitute a kind of epidermal fetishism that fosters fascination with Chinese women among Westerners, by creating a reified object of sexual desire (“Colonial Stereotyping” 137).

Deference to the British permeates Braga's short stories. Colonial governance and exploitation, as concepts, were rigidly stratified in British possessions. Consequently, miscegenation in colonized areas was not uncommon among the English, it nowhere reached the levels attained in Portuguese and Spanish overseas holdings. It is odd, in fact, that while Braga recognizes racial mixing as a feature of Portuguese coloniality, actual relations between colonizers and locals take place in her fiction only among the British or other unspecified "Europeans." It is also peculiar that she describes educated female characters, such as teachers, as able to speak English with great proficiency and carry the title of "Miss.” By excluding her Portuguese compatriots, Braga adds, perhaps 
unconsciously, another layer to the Macanese colonial hierarchy: a subdominant group, the Portuguese. ${ }^{5}$

This issue of hybridity in Braga's stories raises the important issue of character representation. As in the novels of Coates and Fernandes, Braga's male European protagonists serve as powerful colonial stereotypes through their relations with Chinese women. However, Braga breaks entirely with Rey Chow's cited supposition regarding European female protagonists and Chinese men. In her tale "O filho do sol," for example, the uncommon occurs: a white teacher of unspecified nationality becomes pregnant by her Chinese lover. For reasons that Braga does not explain, however, no possibility of marriage between them seems to exist. After visiting a Buddhist temple (rather than a church) to get counseling about her status, she resigns her position as a teacher in a Catholic school. In contradiction to Chow's observation, the plot does not fail.

To return to Gayatri Spivak's provocative question, it is necessary to reiterate that subalterns do in fact speak to an extent in these stories, but only when this category is strictly homogenized and the definition of "to speak" is greatly simplified (Loomba 196). Several female characters in these stories are impoverished Chinese. They, as females of color, symbolize the most exploited of subjugated people: they belong to the lowest and most formalized class of subalterns and, as such, have no history. Most important, as fictional characters, these women are unmistakably patriarchal constructs even though their creators are women. That is, they speak and act as the authors, however well-meaning their intent may be, believe they should. Da Conceição’s writing is a product of coloniality, while Braga's is inseparable from the realities of Portuguese colonialism. However, in softer terms and with some deviation from the construct, both reflect perspectives set forth by patriarchy during subjugation and inherited from the patriarchy after cutting the colonial knot. According to Spivak, if one can speak, one is not a subaltern. So, based on this logic, the subaltern women in these short stories "half speak" at best, an act that raises them perhaps to the category of "fictional semi-altern."

\footnotetext{
${ }^{5}$ It is worth noting that the Anglo-Portuguese alliance formed near the end of the fourteenth century and revised several times afterward, has favored England/the United Kingdom and enabled it to carve out an empire in Africa and Asia at the expense of Portugal. The Portuguese, for their part, have often reluctantly acknowledged British hegemony.
} 


\section{Conclusion}

Though these novels and short stories feature almost exclusively female subaltern protagonists who speak through their respective creators, and though they reflect exoticism, fetishism, patriarchy and hybridity to various degrees, Coates's and Braga's works speak from the vantage point of colonialism, while Fernandes's and da Conceição's creations illustrate the underlying logic of coloniality. In other words, their fictional characters reflect the values and views that colonial Portugal, relying on miscegenation, imposed on its overseas possessions to justify its imperial designs. It is this legacy that must be faced as we work to decolonize all of the Iberian Peninsula's former overseas possessions.

\section{Works Cited}

Bhabha, Homi K. The Location of Culture. Routledge, 1995.

Braga, Maria Ondina. A China fica ao lado. Bertrand, 1974.

Brookshaw, David. Perceptions of China in Modern Portuguese Literature: Border Gates. Mellen, 2002.

Chow, Rey. Ethics after Idealism: Theory, Culture, Ethnicity, Reading. Indiana UP, 1998.

Coates, Austin. City of Broken Promises. Hong Kong UP, 2009.

Da Conceição, Deolinda. Cheong-Sam: a cabaia. Instituto Cultural de Macau/Instituto Português do Oriente, 1995.

Fanon, Frantz. Black Skin, White Masks. Translated by Richard Philcox, Grove, 2008.

Fernandes, Henrique de Senna. A trança feiticeira. Gryphus, 2009.

He, Weihua. "The Prospect of Harmony and the Decolonial View of the World: Weihua He Interviews Walter Mignolo.” Critical Legal Thinking, 12 Jun. 2014, criticallegalthinking.com/2014/06/12/prospect-harmony-decolonialview-mignolo/.

Loomba, Ania. Colonialism/Postcolonialism. Routledge, 2005.

Miu Bing Cheng, Christina. Macau: A Cultural Janus. Hong Kong UP, 1999.

—. "Colonial Stereotyping and Cultural Anthropophagy." Colonizer and Colonized, edited by Theo D’Haen, Rodopi, 2000, pp. 135-49. 
Spivak, Gayatri Chakravorty. “Can the Subaltern Speak?” Marxism and the Interpretation of Culture, edited by Cary Nelson and Lawrence Grossberg, Macmillan, 1988, pp. 271-313. 